\title{
PHYSICAL ACTIVITY IN PREGNANT WOMEN
}

\author{
Jana JUŘÍKOVÁ $\mathbf{1}^{*}$ \\ ${ }^{1}$ Masaryk University, Faculty of Sport Studies, Brno, Czech Republic \\ *Corresponding author: jurikova@fsps.muni.cz
}

https://doi.org/10.35189/dpeskj.2021.60.4.7

\begin{abstract}
Women who are regularly physically active before pregnancy are much more likely to continue to be regularly physically active during pregnancy. There is lack of information on the specific guidelines and real strategies of adapting several recreational and sport activities to healthy pregnant women. The current study investigates knowledge about the suitability of physical activity for pregnant women. The examined women were divided into two groups as follows: active (women who used to perform some leisure physical activity during pregnancy) and non-active (women who did not use to perform any leisure physical activity during pregnancy). Based on the questionnaire responses, it was found that most women participating in this research believed that their information about proper nutrition and the appropriateness of physical activity during gestation were good enough. They named the Internet and television as their primary sources of information. The data analysis revealed that they wrote down in the questionnaires that they insufficiently consumed fish and whole-grain products in general. On the other hand, red meat, poultry, smoked meat and sweets were consumed in excess. Regarding knowledge about the advisability of physical activity during gestation, it was found that most pregnant women appropriately responded to the survey questions.
\end{abstract}

Keywords: pregnant women, physical activity, books, Internet.

\section{Introduction}

Recommendations to move more and sit less will benefit nearly everyone. According to the scientific report issued by the Physical Activity Guidelines Advisory Committee (2008), adults should do at least 150 to 300 minutes of moderate-intensity or 75 to 150 minutes of vigorous-intensity aerobic physical activity per week, or an equivalent combination of moderate-to-vigorous aerobic activity per week. Pregnant women should perform at least 150 minutes of moderate-intensity aerobic activity per week (American College of Obstetricians and Gynecologists, 2015).

Regular physical activity during pregnancy has minimal risks and has been shown to benefit most women. This improves or maintains physical fitness, helps with weight management, reduces the risk of gestational diabetes in obese women and enhances psychological well-being (Piercy et al., 2018).

\section{Methodology}

The questionnaire survey was carried out at the Faculty of Sport Studies, Masaryk University, between 2014 and 2017, and was attended by pregnant women exclusively. It concerns an authorial questionnaire created at the Kinesiology Department of the Faculty of Sport Studies, Masaryk University in Brno, Czech Republic. The questionnaire consists of 23 closed-ended questions, some of them allowing participants to give their own responses. Questions are divided into four categories focusing on general information (age, education, 
place of residence, etc.), eating habits during pregnancy, physical activity during pregnancy and sources of information about nutrition and sport activity during pregnancy. Questionnaires were anonymous, and the rate of return was $90.7 \%$. This study presents the analysis of some questionnaire responses. The questionnaire survey was attended by 107 pregnant women aged 22-44.

Based on the response whether women performed physical activity during pregnancy, they were divided into two groups so that their responses could be examined thoroughly. For the purpose of this study, the group of women who responded that they performed leisure sport activity during pregnancy was called "active" (which relates to this fact solely, without concerning any other activity, i.e., job-related ones). The second group was called "nonactive" and consisted of women who did not perform any leisure physical activity (for health or any other reason). Later in the text, the groups are referred to as "active" and "non-active".

To evaluate the questionnaires results, Microsoft Excel computer programs were used to create a database, and StatK25 (Buňka et al., 2005) was used for statistics. For statistical calculations, the Chi-square test and Kruskall-Wallis test were chosen to compare the file levels. The independence of quantities was determined by contingency tables.

\section{Results}

The questionnaire survey was attended by 107 pregnant women aged 22-44. The categories of respondents are described in Table 1.

Table 1. General characteristics of respondents

\begin{tabular}{cccc}
\hline \multirow{2}{*}{ Characteristic } & \multicolumn{2}{c}{ Pregnant women } & \multirow{2}{*}{ In total } \\
\cline { 2 - 3 } & Active & Non-active & 107 \\
Number of respondents & $68(63.6 \%)$ & $39(36.4 \%)$ & 38 \\
Age & 20 & 18 & 65 \\
$<30$ & 46 & 2 & 4 \\
$30-39$ & 2 & $30.282( \pm 4.362)$ & $31.009( \pm 4.152)$ \\
$40+$ & $31.424( \pm 3.968)$ & 6 & 15 \\
Average age & & 15 & 48 \\
Pregnancy & 9 & 18 & 54 \\
1st trimester & 33 & &
\end{tabular}

As obvious from the table, most women were between 30 and 39 years old, the average age of the whole group being 31.009 ( \pm 4.152$)$ years. The youngest respondents were two 22year-old women, and the two oldest respondents were aged 44 years. Regarding the data in the table, at the significance level of 5\%, no statistically significant differences were found between the two groups of women divided according to their leisure physical activity.

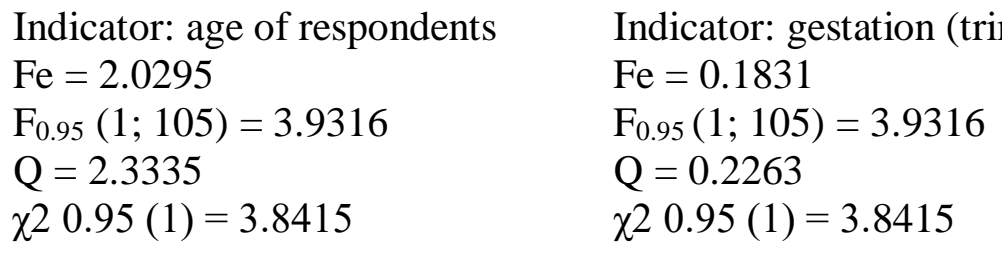


The next question examined whether pregnant women believed that they were sufficiently informed about proper physical activity during pregnancy. Their responses are shown in Figure 1.

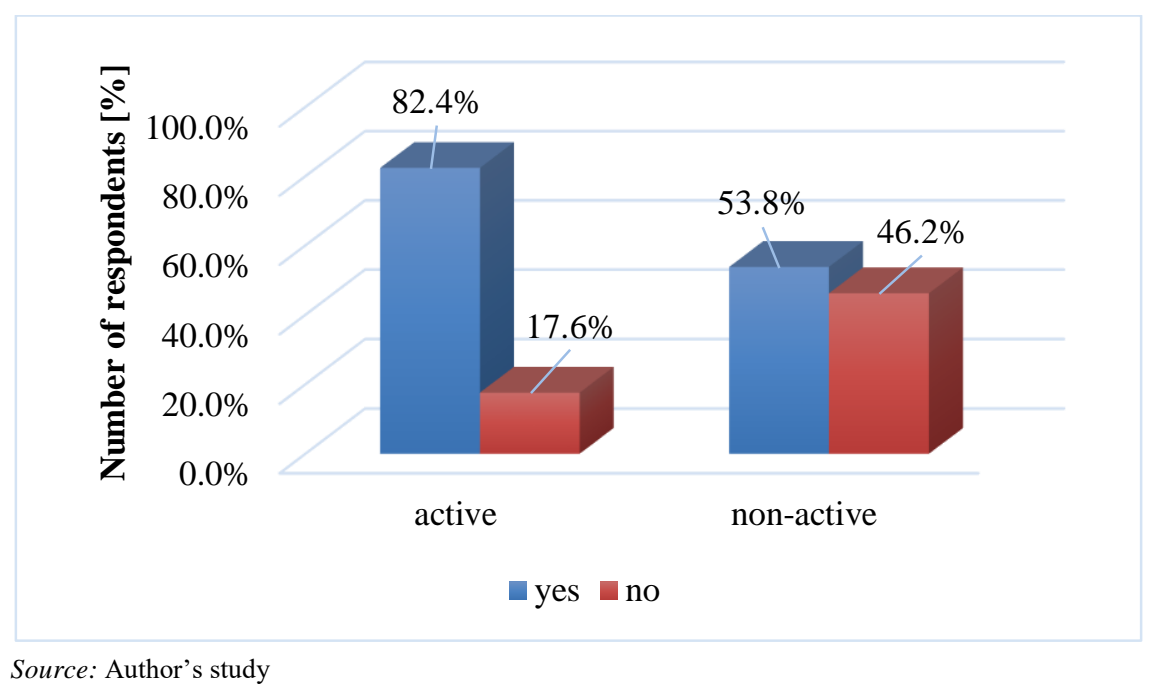

Figure 1. Responses to the question whether pregnant women believe that they are sufficiently informed about proper physical activity during pregnancy

It is apparent that a significantly higher number of respondents from the "active" group $(82.4 \%)$ believe that they are sufficiently informed about proper physical activity during pregnancy. The fact that nearly half $(46.2 \%)$ of non-active women think that they are not sufficiently informed might be one of the reasons why some pregnant women do not perform any physical activity - this was stated by 1 respondent to the questionnaire. At the significance level of 5\%, no statistically significant differences were found between the two groups of pregnant women.

$$
\begin{aligned}
& \mathrm{Fe}=11.6605 \\
& \mathrm{~F}_{0.95}(1 ; 105)=3.9316 \\
& \mathrm{Q}=5.9864 \\
& \chi 20.95(1)=3.8415
\end{aligned}
$$

Women who provided a positive response to the previous question were further asked to name the information source they normally used. The results for all respondents are shown in Figure 2. Responses are given in absolute numbers because participants were allowed to choose more options or give their own responses. 


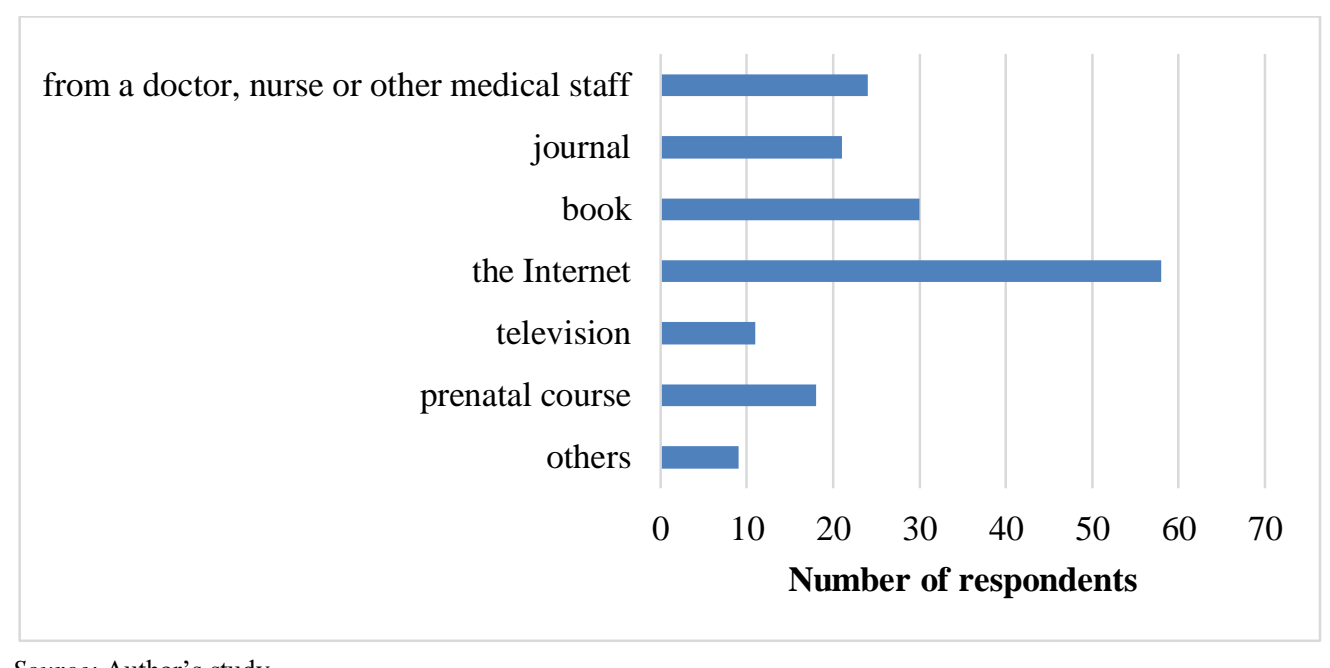

Source: Author's study

Figure 2. Sources of information about proper physical activity for pregnant women used by respondents

As obvious from the above graph, the Internet is the most popular source of information for respondents. Information on the Internet is quickly and easily available from home, but on the other hand, it can also be unprofessional and misleading. The safest source of information is a prenatal course, which was however attended by only 18 women. The option "others" brought responses as follows: school (2x), job (I am a trainer), various courses, mobile applications, yoga instructor, family $(2 \mathrm{x})$, friends.

This question was directly connected with the attempt to find out what particular books or magazines were used by respondents. Among the books available in the Czech Republic, respondents mentioned: Babyweb do ruky [Babyweb in hand], K porodu bez obav [To give birth without worries] (Čermáková, 2017), Fit maminka [Fit mother] (Výborná \& Dočekalová, 2004), Těhotenství [Pregnancy] (Stoppard, 2007), Velká kniha o mateřství [The great book about motherhood] (Behinová, 2007), Velká česká kniha o matce a ditěti [The great Czech book about a mother and child] (Hanáková et al., 2015), Co čekat v radostném očekávání [What to expect in joyful anticipation] (Murkoff et al., 2012). Czech magazines were mainly represented by: "Betynka" [Bety], "Maminka" [Mom], "Moje rodina - Speciál Těhotenství" [My family - A special issue on pregnancy]. Based on this enumeration, one could assume that there are enough literary sources dealing with the issue of physical activity during pregnancy. The next question examines whether respondents agree with this hypothesis. Responses are shown in Figure 3. 


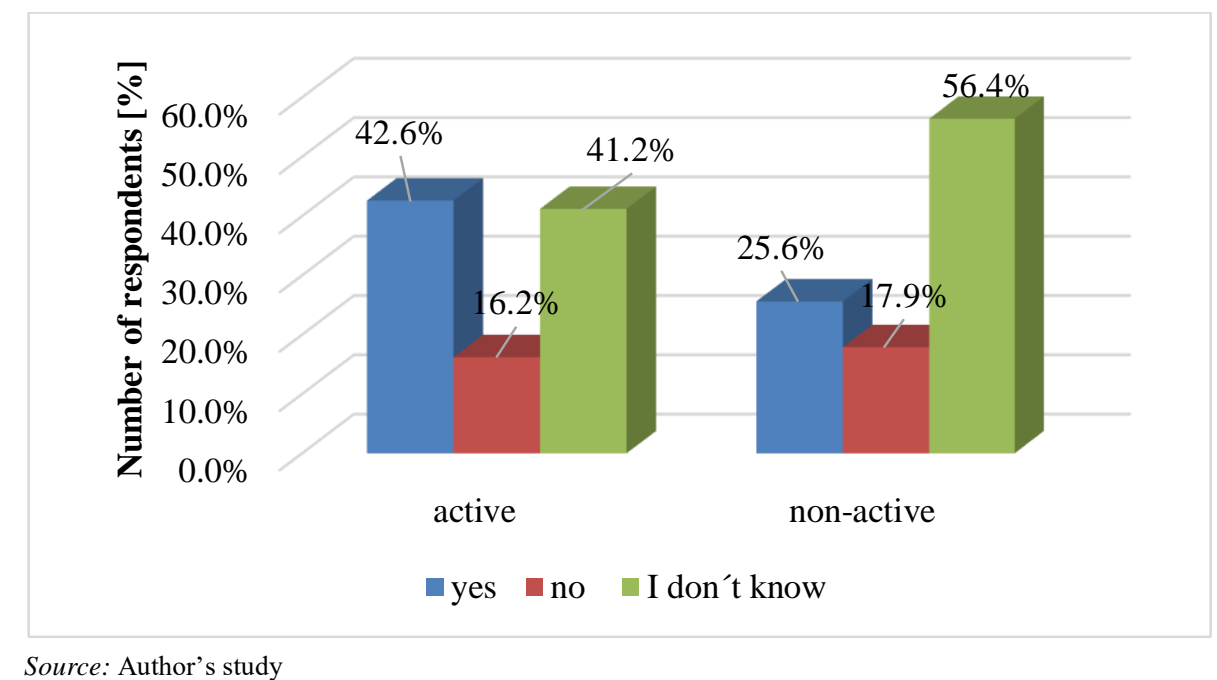

Figure 3. Respondents' opinions on the sufficient amount of literary sources dealing with the issue of "physical activity during pregnancy"

As shown in the above graph, active women are mostly convinced that the number of literary sources is reasonable $(42.6 \%)$. The majority of non-active women $(56.4 \%)$ responded that they did not know, which might well indicate that they were not interested in this issue. At the significance level of $5 \%$, no statistically significant differences were found between the two groups of pregnant women.

$\mathrm{Fe}=3.0949$

$\mathrm{F}_{0.95}(1 ; 105)=3.9324$

$\mathrm{Q}=2.3501$

ఒ2 $0.95(1)=3.8415$

Physical activity during pregnancy is highly important. Table 2 shows women's responses to the question whether they performed any physical activity during pregnancy. Based on their responses, they were further divided into "active" and "non-active".

Table 2. Assigning respondents to the "active" or "non-active" group based on whether they performed any leisure physical activity

\begin{tabular}{ll}
\hline \multicolumn{1}{c}{ Active/Non-active } & Number of women \\
\hline active & 68 \\
non-active & 39 \\
total & 107 \\
\hline Source: Author's study &
\end{tabular}

Women who previously responded in the negative were asked to state the reason why they did not do any exercise. This question was intended only for the "non-active" group of women (39 in total). The most common reasons were the following: lack of time and energy was the first reason; some kinds of aches (i.e., nausea, backache, medical issues, tiredness, pain) were in second place; swollen legs were the next reason; the last reason was taking care of their older child or children. 
The next questions were intended only for women who gave positive responses to the question whether they performed any physical activity, i.e., the question aimed at the "active" group of respondents (68 women in total). One question attempted to find out the place where active pregnant women performed their leisure physical activity. Respondents were offered options to choose or could provide their own responses in the section "others". Responses are shown in Figure 4.

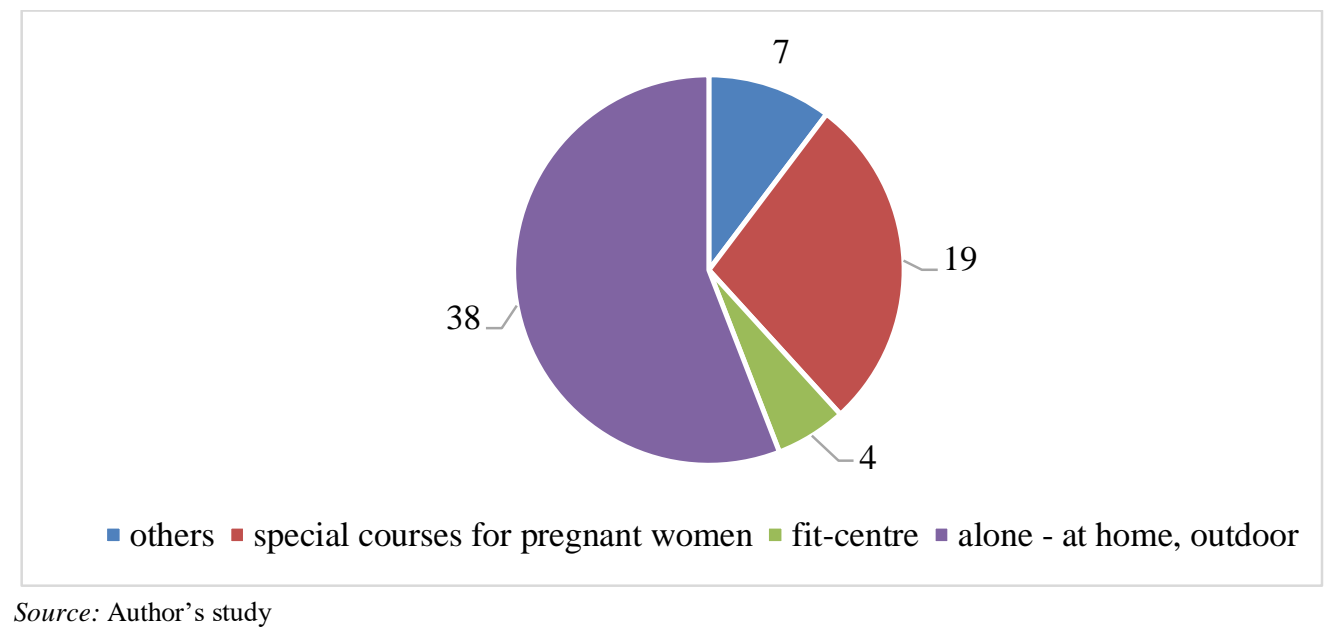

Figure 4. Place where active respondents perform their physical activity

The graph shows that most respondents perform physical activity on their own either at home (typically with an instructional DVD) or outdoors, often with their dogs, which ensures a brisk walking pace, as stated by a respondent: "I must be as fast as my hunting dog needs". The option "others" brought responses as follows: walk, 5-km walk, swimming in a pool, long walks, yoga, RM system, group exercise not especially designed for pregnant women.

The next question tries to find out what physical activity is the most popular among pregnant women. If they performed more than one activity, they were allowed to choose more options or possibly write their own responses. These responses are shown in Figure 5.

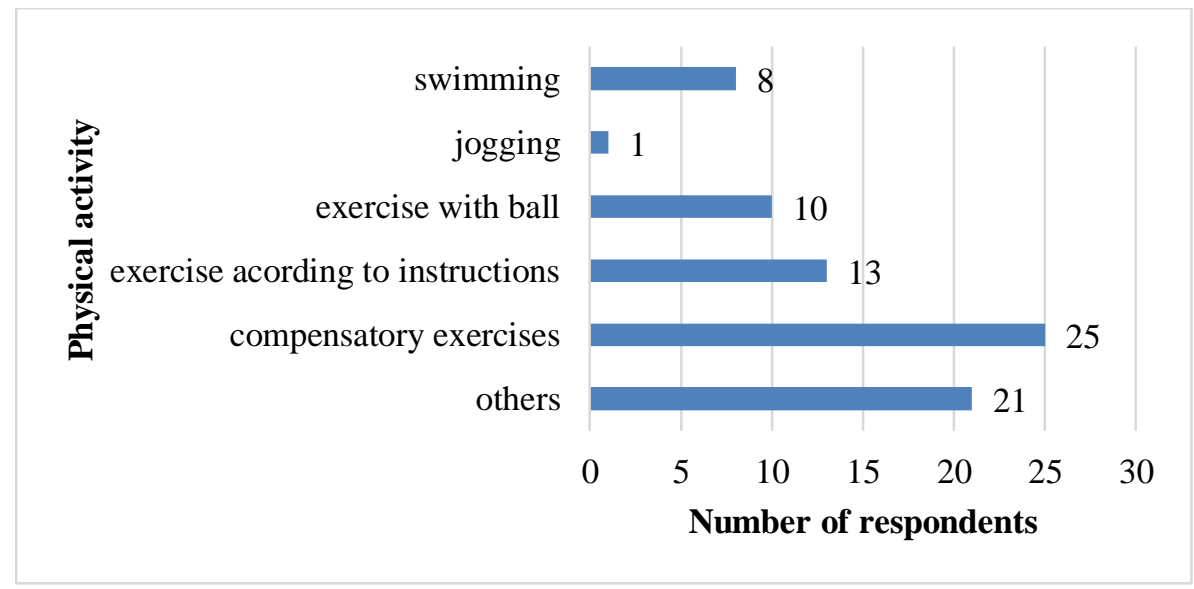

Source: Author's study

Figure 5. Leisure physical activities performed by pregnant women 
The above graph shows that compensatory exercises are the most popular physical activity for respondents. These involve stretching and relaxing exercises that are suitable even for women who had not practised any exercise prior to pregnancy. The option "others" brought responses as follows: long walks, stretching, yoga, Pilates, spinner, rehabilitation exercises for mothers-to-be (these activities are highly recommended), cycling (recommended, but indoor cycling is preferred due to possible fall) and scooter ride. One woman even mentioned skiing, which is not a suitable physical activity for pregnant women due to the risk of falls and crashes that might lead to abdominal area injury or contusion (Pařízek, 2015).

The next question focused on the frequency of physical activity in active women. Their responses are shown in Figure 6.

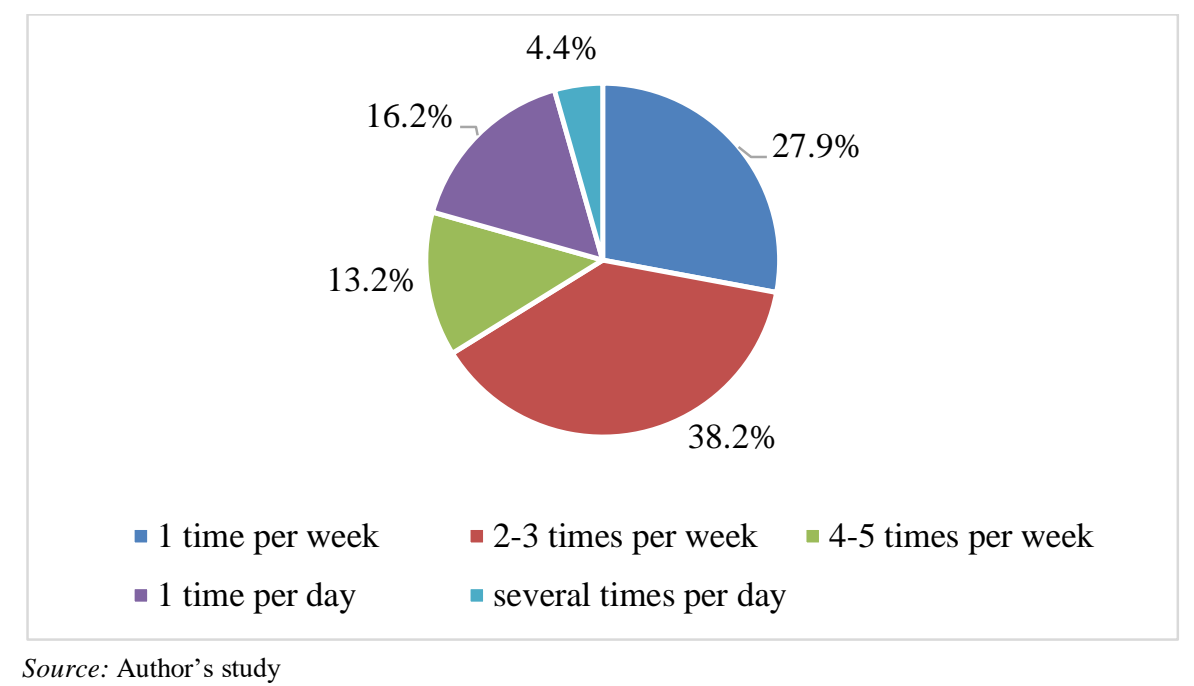

Figure 6. Frequency of physical activity in the active group of respondents

Some sources recommend that pregnant women perform physical activity at least 30 minutes per day and gradually increase exercise intensity from medium to high, unless prohibited by a doctor (American College of Obstetricians and Gynecologists, 2003). Medium intensity is understood as a brisk walk (Haskell et al., 2007). According to the above graph, it is apparent that the majority of respondents (38.2\%) perform physical activity 2-3 times per week and merely $16.2 \%$ of them exercise on a daily basis.

\section{Discussion}

These findings are consistent with the study by Beckham et al. (2015), which focuses on pregnant women's knowledge about proper nutrition and physical activity, with most participants responding "I do not know". However, some women recognised the importance of proper nutrition and physical activity during pregnancy, but they did not know what nutrition recommendations or physical activities were suitable for them. Although many studies prove that physical activity during pregnancy is safe and efficient for the optimal weight of both the mother and her future child (Sui \& Dodd, 2013; Loterging, 2014; Mourtakos et al., 2015; Mattran et al., 2011), a large number of pregnant women say that they 
have no knowledge or information about the positive effect of physical activity on their physical condition (Stengel et al., 2012; Ferrari, 2013; Williams et al., 2016).

A recent study by Nascimento et al. (2015) has concluded that most pregnant women do not obtain relevant information or the opportunity to perform physical activity from medical institutions. Similar findings are reported by Gaston and Vamos (2013), who have found that pregnant women give up physical activity without the support of medical staff.

Women who are not physically active have some reasons for this. Some might feel nausea when lying on their back. Due to the growing weight of the foetus, an effort or a long time spent lying on the back might decrease venous return of blood and minute cardiac output (American College of Sports Medicine, 2017). Starting with the 16th week of pregnancy, women are recommended to continue physical activity but avoid this position (American College of Obstetricians and Gynecologists, 2015; Canadian Society for Exercise Physiology, 2015). Most pregnant women suffer from low back pain and pelvic girdle pain due to changes in the centre of gravity and excessive loading of muscles and ligaments. However, these women are advised to exercise, given that numerous studies have proven the positive effect of exercise on reducing low back pain (Abu et al., 2017; Watelain et al., 2017; Šklempe Kokić et al., 2017). Once medical problems have been resolved, most women are able to resume physical activity, sometimes after only minor adjustments.

Unfortunately, research shows that doctors have conservative attitudes and do not support pregnant women to exercise (Szumilewicz, 2018). The study by Wojtyła et al. (2012) revealed that about $11 \%$ of pregnant women reduced their physical activity without any medical reason. Swollen legs can be caused by impaired return of blood from the lower limbs to the heart due to the enlarging uterus. This can be prevented by standing upright for longer periods or sitting cross-legged. Swelling is not a reason to give up physical activity since proper exercise can prevent or at least reduce it. (Vitíková, 2007; Beránková, 2000) Another preventive measure is to wear compression stockings that must be put on early in the morning to reach an optimal effect (Dumoulin, 2006; Wessels \& Oellerich, 2009; Hrobařová, 2014).

Women in foreign studies argue that, despite the wide range of information sources involving medical care institutions, family, friends, printed materials, the Internet and the media, exercise is sometimes a confusing and ambiguous topic (Clarke \& Gross, 2004; Lewalien, 2004; Krans et al., 2005; Doran \& O’Brien, 2007). Other studies agree that exercise is not discussed with pregnant women (Entin \& Munhall, 2006; Evenson \& Bradley, 2010).

Recent foreign studies prove that leisure physical activity during pregnancy is related to lower birth weight than standard parameters and reduces the risk that a new-born baby grows bigger than their gestational age (Hegaard et al., 2007; Owe et al., 2009; Voldner et al., 2008; Mattran et al., 2011). As obvious from Table 1, most respondents (63.6\%) are engaged in leisure physical activity. This is quite a positive finding in comparison with an American study that revealed that only $23 \%$ of pregnant women did leisure physical activity (Evenson \& Wen, 2010; Williams et al., 2016).

Numerous obstacles that prevent pregnant women from doing physical activity are found in foreign studies as well, for example, nausea, job duties, taking care of older children (Weir et al., 2010), mistrust of safety during exercise (Bennett et al., 2013) and physical restrictions caused by changed body proportions (Carolan et al., 2012; Hegaard et al., 2010). Other 
factors such as the emotional and mental impact of these exercises or lack of physical or social opportunities are also likely to weaken their motivation (Olander et al., 2016; Atkinson et al., 2016). Other studies suggest more obstacles that prevent pregnant women from doing physical activity: lack of time, lack of equipment or facilities, no opportunity for baby-sitting (Pereira et al., 2007; Symons-Downs \& Hausenblas, 2004; Thompton et al., 2006; Evenson et al., 2008). Some women even consider that physical activity during pregnancy is dangerous (Duncombe et al., 2009; Clarke \& Gross, 2004; Weir et al., 2010).

According to the American College of Obstetricians and Gynecologists (2015), pregnant women are recommended to perform physical activity such as walking, hiking, jogging, aerobics, dancing, swimming or cycling (Ko et al., 2016), which is in agreement with several Czech authors (i.e., Pařízek, 2015; Bejdáková, 2006).

Some studies from abroad also reveal differences between recommendations and the actual situation, in other words, how often pregnant women actually perform physical activity (Evenson et al., 2002; Petersen et al., 2005). Women often have less physical activity than recommended (Haakstad et al., 2007) and, with advancing pregnancy, tend to reduce it even more (Rousham et al., 2006; Weir et al., 2010). Other sources suggest an overall mediumintensity activity for at least 150 minutes per week or maintaining the pre-pregnancy activity and gradually adjusting its intensity according to recommendations (Physical Activity Guidelines Advisory Committee, 2008; Wolfe \& Davies, 2003; Sanda et al., 2017).

\section{Conclusion}

Two thirds $(63.6 \%)$ of respondents perform physical activity during pregnancy. Based on this, the group of respondents was divided into "active" and "non-active".

The questionnaire survey highlights that most pregnant women believe that they are properly informed about relevant physical activity during pregnancy, and this response is given by $82.4 \%$ of pregnant women who perform physical activity (active women) and $53.8 \%$ of those who do not perform any physical activity during pregnancy (non-active women). More than half of respondents (58 people) use the Internet to seek information.

Women who claim to be physically active usually do the activity on their own either at home or outdoors (a response given by $38 \%$ of active women). The most popular physical activity is compensatory exercise ( 25 respondents chose this option), which reduces low back pain. $38.2 \%$ of active women get engaged in leisure physical activity 2-3 times per week, which was the most common response.

\section{References}

Abu, M. A., Abdul Ghani, N. A. A., Shan, L. P., Sulaiman, A. S., Omar, M. H., Ariffin, M. H. M., Baharuddin, A., Shohaimi, S., \& Man, Z. C. (2017). Do exercises improve back pain in pregnancy? Hormone Molecular Biology and Clinical Investigation, 32(3). https://doi.org/10.1515/hmbci-2017-0012

American College of Obstetricians and Gynecologists. (2003). Exercise during pregnancy and the postpartum period. Clinical Obstetrics and Gynecology, 46(2), 496-499. https://doi.org/10.1097/00003081-200306000-00028 
American College of Obstetricians and Gynecologists. (2015). ACOG Committee Opinion No. 650: Physical activity and exercise during pregnancy and the postpartum period. Obstetrics \& Gynecology, 126(6), e135-e142. https://doi.org/10.1097/aog.0000000000001214

American College of Sports Medicine. (2017). ACSM's guidelines for exercise testing and prescription. Williams \& Wilkins.

Atkinson, L., Shaw, R. L., \& French, D. P. (2016). Is pregnancy a teachable moment for diet and physical activity behaviour change? An interpretative phenomenological analysis of the experiences of women during their first pregnancy. British Journal of Health Psychology, 21(4), 842-858. https://doi.org/10.1111/bjhp.12200

Beckham, A. J., Urrutia, R. P., Sahadeo, L., Corbie-Smith, G., \& Nicholson, W. (2015). "We know but we don't really know": Diet, physical activity and cardiovascular disease prevention knowledge and beliefs among underserved pregnant women. Maternal and Child Health Journal, 19(8), 1791-1801. https://doi.org/10.1007/s10995-015-1693-2

Bennett, E. V., McEwen, C. E., Hurd Clarke, L., Tamminen, K. A., \& Crocker, P. R. E. (2013). "It's all about modifying your expectations": Women's experiences with physical activity during pregnancy. Qualitative Research in Sport, Exercise and Health, 5(2), $267-$ 286. https://doi.org/10.1080/2159676X.2013.766812

Beránková, B. (2000). Cvičení v těhotenství [Exercise in pregnancy]. Praha: Institut pro další vzdělávání pracovníků ve zdravotnictví.

Buňka, F., Kř́̌ž, O., \& Hrabě, J. (2005). Základní manuál ke statistickému softwaru STATVYD verze 2.0 beta [Basic manual for STATVYD statistical software, version 2.0 beta]. Zlín: Univerzita Tomáše Bati ve Zlíně.

Carolan, M., Gill, G. K., \& Steele, C. (2012). Women's experiences of factors that facilitate or inhibit gestational diabetes self-management. BMC Pregnancy Childbirth, 12: 99. https://doi.org/10.1186/1471-2393-12-99

Clarke, P. E., \& Gross, H. (2004). Women's behaviour, beliefs and information sources about physical exercise in pregnancy. Midwifery, 20(2), 133-141.

https://doi.org/10.1016/j.midw.2003.11.003

Canadian Society for Exercise Physiology. (2015). PARmed-X for Pregnancy: Physical Activity Readiness Medical Examination. https://vancouver.ca/files/cov/par-q-plus-form-for-pregnancy-before-exercising.pdf

Doran, F., \& O'Brien, A. P. (2007). A brief report of attitudes towards physical activity during pregnancy. Health Promotion Journal of Australia, 18(2), 155-158. https://doi.org/10.1071/he07155

Dumoulin, C. (2006). Cvičíme v těhotenství: Názorný popis cviků a praktické rady [Exercising in pregnancy: An illustrative description of exercises and practical advice]. Portál.

Duncombe D., Wertheim, E. H., Skouteris, H., Paxton, S. J., \& Kelly, L. (2009). Factors related to exercise over the course of pregnancy including women's beliefs about the safety of exercise in pregnancy. Midwifery, 25(4), 430-438. https://doi.org/10.1016/j.midw.2007.03.002

Entin, P. L., \& Munhall, K. M. (2006). Recommendations regarding exercise during pregnancy made by private/small group practice obstetricians in the USA. Journal of Sports Science \& Medicine, 5(3), 449-458. PMID: 24353463

Evenson, K. R., \& Bradley, C. B. (2010). Beliefs about exercise and physical activity among pregnant women. Patient Education and Counseling, 79(1), 124-129.

https://doi.org/10.1016/j.pec.2009.07.028 
Evenson, K. R., \& Wen, F. (2010). National trends in self-reported physical activity and sedentary behaviors among pregnant women: NHANES 1999-2006. Preventive Medicine, 50(3), 123-128. https://doi.org/10.1016/j.ypmed.2009.12.015

Evenson, K. R., Moos, M.-K., Carrier, K. S., \& Siega-Riz, A. M. (2008). Perceived barriers to physical activity among pregnant women. Maternal and Child Health Journal, 13(3), 364-375. https://doi.org/10.1007/s10995-008-0359-8

Evenson, K. R., Siega-Riz, A. M., Savitz, D. A., Leiferman, J. A., \& Thorp, J. M. Jr. (2002). Vigorous leisure activity and pregnancy outcome. Epidemiology, 13(6), 653-659. https://doi.org/10.1097/00001648-200211000-00009

Ferrari, R. M., Siega-Riz, A. M., Evenson, K. R., Moos, M.-K., \& Carrier, K. S. (2013). A qualitative study of women's perceptions of provider advice about diet and physical activity during pregnancy. Patient Education and Counseling, 91(3), 372-377. https://psycnet.apa.org/doi/10.1016/j.pec.2013.01.011

Gaston, A., \& Vamos, C. A. (2013). Leisure-time physical activity patterns and correlates among pregnant women in Ontario, Canada. Maternal and Child Health Journal, 17(3), 477-484. https://doi.org/10.1007/s10995-012-1021-z

Haakstad, L. A. H., Voldner, N., Henriksen, T., \& Bo, K. (2007). Physical activity level and weight gain in a cohort of pregnant Norwegian women. Acta Obstetricia et Gynecologica Scandinavica, 86(5), 559-564. https://doi.org/10.1080/00016340601185301

Haskell, W. L., Lee, I.-M., Pate, R. R, Powell, K. E., Blair, S. N., Franklin, B. A., Macera, C. A., Heath, G, W., Thompson, P. D., \& Bauman, A. (2007). Physical activity and public health updated recommendation for adults from the American College of Sports Medicine and the American Heart Association. Medicine \& Science in Sports \& Exercise, 39(8), 1423-1434. https://doi.org/10.1249/mss.0b013e3180616b27

Hegaard, H. K., Kjaergaard, H., Damm, P. P., Petersson, K., \& Dykes, A.-K. (2010). Experiences of physical activity during pregnancy in Danish nulliparous women with a physically active life before pregnancy. A qualitative study. BMC Pregnancy and Childbirth, 10: 33. https://doi.org/10.1186/1471-2393-10-33

Hegaard, H. K., Pedersen, B. K., Bruun Nielsen, B., \& Damm, P. (2007). Leisure time physical activity during pregnancy and impact on gestational diabetes mellitus, preeclampsia, preterm delivery and birth weight: A review. Acta Obstetricia et Gynecologica Scandinavica, 86(11), 1290-1296. https://doi.org/10.1080/00016340701647341

Hrobařová, J. (2014). Životospráva těhotných žen [Life management of pregnant women]. Olomouc, Univerzita Palackého.

Ko, Y.-L., Chen, C.-P., \& Lin, P.-C. (2016). Physical activities during pregnancy and type of delivery in nulliparae. European Journal of Sport Science, 16(3), 374-380. https://doi.org/10.1080/17461391.2015.1028468

Krans, E. E., Gearhart, J. G., Dubbert, P. M., Klar, P. M., Miller, A. L., \& Replogle, W. H. (2005). Pregnant women's beliefs and influences regarding exercise during pregnancy. Journal of the Mississippi State Medical Association, 46(3), 67-73. PMID: 15822648

Lewalien, L. P. (2004). Healthy behaviors and sources of heath information among lowincome pregnant women. Public Health Nursing, 21(3), 200-206. https://doi.org/10.1111/j.0737-1209.2004.021302.x

Loterging, F. K. (2014). 30(+) years of exercise in pregnancy. In L. Zhang \& C. Ducsay (Eds.), Advances in experimental medicine and biology (Vol. 814: Advances in fetal and neonatal physiology, pp. 109-116). Springer. https://doi.org/10.1007/978-1-4939-1031-1_10

Mattran, K., Mudd. L. M., Rudey, R. A., \& Kelly, J. S. (2011). Leisure-time physical activity during pregnancy and offspring size at 18 to 24 months. Journal of Physical Activity \& Health, 8(5), 655-662. https://doi.org/10.1123/jpah.8.5.655 
Mourtakos, S. P., Tambalis, K. D., Panagiotakos, D. B., Antonogeorgos, G., Arnaoutis, G., Karteroliotis, K., \& Sidossis, L. S. (2015). Maternal lifestyle characteristics during pregnancy, and the risk of obesity in the offspring: A study of 5,125 children. BMC Pregnancy and Childbirth, 15: 66. https://doi.org/10.1186/s12884-015-0498-Z

Nascimento, S. L., Surita, F. G., Godoy, A. C., Kasawara, K. T., \& Morais, S. S. (2015). Physical activity patterns and factors related to exercise during pregnancy: A cross sectional study. PLoS One, 10(6): e0128953. https://doi.org/10.1371/journal.pone.0128953

Olander, E. K., Darwin, Z. J., Atkinson, L., Smith, D. M., \& Gardener, B. (2016). Beyond the "teachable women": Conceptual analysis of women's perinatal behavior change. Women and Birth, 29(3), e67-e71. https://doi.org/10.1016/j.wombi.2015.11.005

Owe, K. M., Nystad, W., \& Bo, K. (2009). Association between regular exercise and excessive newborn birth weight. Obstetrics \& Gynecology, 114(4), 770-776. https://doi.org/10.1097/aog.0b013e3181b6c105

Physical Activity Guidelines Advisory Committee. (2008). Physical Activity Guidelines Advisory Committee Report. U.S. Department of Health and Human Services. https://www.europarc.org/wp-content/uploads/2018/03/Physical-Activity-GuidelinesAdvisory-Committee-Report-2008.pdf

Pařízek, A. (2015). Kniha o těhotenství, porodu a dítěti: Těhotenství [A book about pregnancy, childbirth and the baby: Pregnancy]. Galén.

Pereira, M. A., Rifas-Shiman, S. L., Kleinman, K. P., Rich-Edwards, J. W., Peterson, K. E., \& Gillman, M. V. (2007). Predictors of change in physical activity during and after pregnancy: Project Viva. American Journal of Preventive Medicine, 32(4), 312-319. https://doi.org/10.1016/j.amepre.2006.12.017

Petersen, A. M., Leet, T. L., \& Brownson, R. C. (2005). Correlates of physical activity among pregnant women in the United States. Medicine \& Science in Sports \& Exercise, 37(10), 748-753. https://doi.org/10.1249/01.mss.0000181302.97948.90

Piercy, K. L., Trojano, R. P., Ballard, R. M., Carlson, S. A., Fulton, J. E., Galuska, D. A., George, S. M., \& Olson, R. D. (2018). The Physical Activity Guidelines for Americans. JAMA, 320(19), 2020-2028. https://doi.org/10.1001/jama.2018.14854

Rousham, E. K., Clarke, P. E., \& Gross, H. (2006). Significant changes in physical activity among pregnant women in the UK as assessed by accelerometry and self-reported activity. European Journal of Clinical Nutrition, 60(3), 393-400. https://doi.org/10.1038/sj.ejen.1602329

Sanda, B, Vistad, I., Haakstad, L. A. H., Berntsen, S., Sagedal, L. R., Lohne-Seiler, H., \& Torstveit, M. K. (2017). Reliability and concurrent validity of the international physical activity questionnaire short form among pregnant women. BMC Sports Science, Medicine and Rehabilitation, 9(7). https://doi.org/10.1186/s13102-017-0070-4

Šklempe Kokić, I., Ivanišević, M., Uremović, M., Kokić, T., Pišot, R., \& Šimunić, B. (2017). Effect of therapeutic exercises on pregnancy-related low back pain and pelvic girdle pain: Secondary analysis of a randomized controlled trial. Journal of Rehabilitation Medicine, 49(3), 251-257. https://doi.org/10.2340/16501977-2196

Stengel, M. R., Kraschnewski, J. L., Hwang, S. W., Kjerulff, K. H., \& Chuang, C. H. (2012). "What my doctor didn't tell me": Examining health care provider advice to overweight and obese pregnant women on gestational weight gain and physical activity. Women's Health Issues, 22(6), e535-e540. https://doi.org/10.1016/j.whi.2012.09.004

Sui, Z, \& Dodd, J. M. (2013). Exercise in obese pregnant women: positive impacts and current perceptions. International Journal of Women's Health, 5, 389-398. https://doi.org/10.2147/ijwh.s34042 
Symons-Downs, D., \& Hausenblas, H. A. (2004). Women's exercise beliefs and behaviours during their pregnancy and postpartum. Journal of Midwifery and Women's Health, 49(2), 138-144. https://doi.org/10.1016/j.jmwh.2003.11.009

Szumilewicz, A. (2018). Who and how should prescribe and conduct exercise programs for pregnant women? Recommendations based on the European educational standards for pregnancy and postnatal exercise specialists. Developmental Period Medicine, 22(2), $107-$ 112.

Thompton, P. I., Kieffer, E. D., Salabarria-Pena, Y., Odoms-Young, A., Wills, S. K., Kim, H., \& Salinas, M. A. (2006). Weight, diet, and physical activity-related beliefs and practices among pregnant and postpartum Latino women: The role of social support. Maternal and Child Health Journal, 10(1), 95-104. https://doi.org/10.1007/s10995-005-0025-3

Vitíková, R. (2007). Těhotenství a šestinedělí v kondici [To be in shape for pregnancy and postpartum]. Galén.

Voldner, N., Frøslie, K. F., Bo, K., Haakstad, L., Hoff, C., Godang, K., Bollerslev, J., \& Henriksen, T. (2008). Modifiable determinants of fetal macrosomia: Role of lifestylerelated factors. Acta Obstetricia et Gynecologica Scandinavica, 87(4), 423-429. https://doi.org/10.1080/00016340801989825

Watelain, E., Pinti, A., Doya, R., Garnier, C., Toumi, H., \& Boudet, S. (2017). Benefits of physical activities centered on the trunk for pregnant women. Physical Sportsmedicine, 45(3), 293-302. https://doi.org/10.1080/00913847.2017.1351286

Weir, Z, Bush, J., Robson, S. C., McParlin, C., Rankin, J., \& Bell, R. (2010). Physical activity in pregnancy: A qualitative study of the beliefs of overweight and obese pregnant women. BMC Pregnancy and Childbirth, 10: 18. https://doi.org/10.1186/1471-2393-10-18

Wessels, M., \& Oellerich, H. (2009). Wellness jóga pro těhotné. Blahodárná cvičení pro vás a vaše ditě [Wellness yoga for pregnant women. Beneficial exercises for you and your child]. Grada.

Williams, K., Brown, A., Crandall, K. J., \& Tinius, R. A. (2016). Educational information improves physical activity knowledge during pregnancy. KAHPERD Journal, 54(1), 3545.

Wojtyła, A., Kapka-Skryzpczak, L., Paprzycki, P., Skrzypczak, M., \& Biliński, P. (2012). Epidemiological studies in Poland on the effect of physical activity of pregnant women on the health of offspring and future generations - Adaptation of the hypothesis development origin of health and diseases. Annual Agricultural and Environmental Medicine, 19(2), 315-326. PMID: 22742808

Wolfe, L. A., \& Davies, G. A. L. (2003). Canadian guidelines for exercise in pregnancy. Clinical Obstetrics \& Gynecology, 46(2), 488-495. https://doi.org/10.1097/00003081-200306000-00027 